\title{
Perbedaan Motivasi Wanita PUS Usia 35-49 Tahun untuk Menggunakan Implant Sebelum dan Setelah Diberi Penyuluhan di Dusun Mojolegi Desa Bendo Kec. Pare.
}

(The Difference Motivation of Childbearing Age Couples Women in Age 35-49 years to Use Implants Before and After Giving Information in Mojolegi Hamlet Bendo Village Pare District)

\author{
Triatmi Andri Yanuarini, Susanti Pratamaningtyas, Rika Aprilia Susanti. \\ Poltekkes Kemenkes Malang \\ Prodi Kebidanan Kediri Jl.KH.Wakhid Hasyim 64 B Kediri
}

\begin{abstract}
Women who have age $35^{\text {th }}$ years old need safety and effective contraception because these group will get increased morbidity and mortality experience if they pregnant. Implant is one method of effective an safety long-term contraception. Bendo Health Center have the lowest acceptor implants in Kediri that is $0 \%$. The purpose of this research to know the difference motivation of childbearing age couples women in age 35-49 years to use implant before and after giving information. The design used a pre-experiment design with one group pre-test post-test design, the population was all childbearing age couples women in age 35-49 years at Mojolegi Hamlet Bendo Village Pare District who have children, not use contraception or still use non-Long Term contraception Method which total 72 people. The samplehave a lot 61 people according to inclusion and exclusion criteria. The sample removal technique used simple random sampling. The result of this research, from 61 respondents get average of respondent motivation before give information is 65 and after give information is 69, show that respondent's motivation get increase after got information. And after going through the data analysis it was found $\mathrm{z}$ calculate $>\mathrm{z}$ table, so in this case have difference motivation of childbearing age couples women in age 35-49 years to use implants before and after giving information.
\end{abstract}

Keywords: Counseling, Motivation, Implants

\section{Pendahuluan}

Indonesia menghadapi masalah dengan jumlah dan kualitas sumber daya manusia dengan kelahiran 5.000 .000 per tahun (Manuaba, IBG, dkk. 2010: 591). Pertumbuhan penduduk di Indonesia berkisar antara $2,15 \%$ hingga $2,49 \%$ per tahun. Tingkat pertumbuhan penduduk seperti itu dipengaruhi oleh tiga faktor utama, yaitu: kelahiran (fertilitas), kematian (mortalitas), dan perpindahan penduduk (migrasi). Pertumbuhan penduduk seperti dikemukakan diatas dapat dikatakan terlalu tinggi karena dapat menimbulkan berbagai persoalan (Arum, Dyah, dkk. 2009: 3). Pendapat Malthus yang mengemukakan bahwa pertumbuhan dan kemampuan mengembangkan sumber daya alam laksana deret hitung, sedangkan pertumbuhan dan perkembangan manusia laksana deret ukur, sehingga pada satu titik sumber daya alam tidak mampu menampung pertumbuhan manusia - telah menjadi kenyataan. Berdasarkan pendapat demikian diharapkan setiap keluarga memperhatikan dan merencanakan jumlah keluarga yang diinginkan. (Manuaba, IBG, dkk. 2010: 591)

BKKBN sebagai lembaga pemerintah di Indonesia mempunyai tugas untuk mengendalikan fertilitas melalui pendekatan 4 (empat) pilar program, yaitu Program Keluarga Berencana (KB), Kesehatan Reproduksi (KR), Keluarga Sejahtera (KS) dan Pemberdayaan Keluarga (PK). Dalam Rencana Pembangunan Jangka Menengah Nasional 
(RPJMN) tahun 2009-2014, tertuang bahwa dalam rangka mempercepat pengendalian fertilitas melalui penggunaan kontrasepsi, program keluarga berencana nasional di Indonesia lebih diarahkan kepada pemakaian Metoda Kontrasepsi Jangka Panjang (MKJP). Metoda Kontrasepsi Jangka Panjang adalah kontrasepsi yang dapat dipakai dalam jangka waktu lama, lebih dari dua tahun, efektif dan efisien untuk tujuan pemakaian menjarangkan kelahiran lebih dari 3 tahun atau mengakhiri kehamilan pada pasangan yang sudah tidak ingin tambah anak lagi. Jenis metoda yang termasuk dalam kelompok ini adalah metoda kontrasepsi mantap (pria dan wanita), Implant, dan Intra Uterine Device (IUD). (BKKBN, 2009)

Berdasarkan hasil Survei Demografi dan Kependudukan Indonesia tahun 2012, angka pemakaian kontrasepsi modern bagi wanita di Indonesia adalah suntik sebesar $31,9 \%$, pil $13,6 \%$, IUD 3,9 \%, Implant $3,3 \%$, MOW 3,2 \%. Sementara angka pemakaian kontrasepsi modern bagi wanita di Provinsi Jawa timur adalah suntik sebesar $34,7 \%$, pil $14,7 \%$, IUD $5,0 \%$, Implant 3,1 \%, MOW 3,5\% (SDKI, 2012).

Perempuan berusia lebih dari 35 tahun memerlukan kontrasepsi yang aman dan efektif karena kelompok ini akan mengalami peningkatan morbiditas dan mortalitas jika mereka hamil (Saifuddin, Abdul Bari. 2010: U-49). Penggunaan kontrasepsi paling rendah adalah Implant, padahal Implant dapat digunakan pada perempuan $>35$ tahun yang menginginkan kontrasepsi jangka panjang. (Saifuddin, Abdul Bari. 2006: U-50). Selain itu Implant memiliki angka kegagalan yang lebih rendah dibandingkan kontrasepsi oral, IUD dan metode barier, yaitu hanya $<1$ per 100 wanita per tahun dalam 5 tahun pertama. (Hartanto, Hanafi. 2004: 182). Implant dapat dipakai jangka panjang, yaitu daya kerjanya sampai 5 tahun pada norplant 6 kapsul (Hartanto, Hanafi. 2004: 179). Implant hanya sedikit sekali menyebabkan efek samping lain disamping perubahan haid dan hanya sedikit sekali menyebabkan perubahanperubahan sistemik (Hartanto, Hanafi. 2004: 184).

Hasil penelitian yang dilakukan oleh Musdalifah dkk mengenai faktor yang berhubungan dengan pemilihan alat kontrasepsi hormonal, mengatakan bahwa ada hubungan antara umur, dukungan suami, efek samping dan pemberian informasi petugas $\mathrm{KB}$ dengan pemilihan alat kontrasepsi hormonal (Musdalifah, dkk. 2013). Menurut BKKBN 2009, peran petugas $\mathrm{KB}$, tokoh agama, tokoh masyarakat dan media dalam memberikan informasi $\mathrm{KB}$ masih rendah ( $<20$ persen). (BKKBN, 2009)

Berdasarkan hasil studi pendahuluan pada tanggal 5 Februari 2014 di Dinkes Kabupaten Kediri, angka pemakaian kontrasepsi modern bagi wanita di Kabupaten Kediri tertinggi adalah suntik sebesar 70,24 \%, diikuti pil $12,11 \%$, IUD $9,5 \%$, MOW 4,36 \%, dan Implant menempati angka terendah dengan 2,49 $\%$. Puskesmas Puncu memiliki jumlah akseptor Implant tertinggi di Kabupaten Kediri yaitu 462 akseptor dengan prosentase 6,49 \%, sementara Desa Bendo memiliki jumlah akseptor Implant terendah yaitu sebesar $0 \%$.

Sesuatu yang mendorong Ibu dalam memakai suatu alat kontrasepsi disebut motivasi. Motivasi merupakan sesuatu yang menggerakkan atau mendorong seseorang atau sekelompok orang untuk melakukan atau tidak melakukan sesuatu. Motivasi dipengaruhi oleh faktor-faktor tingkat pengetahuan, keyakinan atau kepercayaan, sarana yang diperlukan, dan dorongan. (Haska, Ardani: 2003)

Dari penelitian yang telah dilakukan oleh Musdalifah dkk dan menurut BKKBN diatas dapat disimpulkan bahwa pemberian informasi atau penyuluhan berpengaruh dalam pemilihan metode kontrasepsi. Promosi kesehatan atau penyuluhan kesehatan adalah kegiatan pendidikan yang dilakukan dengan cara 
menyebarkan pesan, menambahkan keyakinan, sehingga masyarakat tidak saja sadar, tahu dan mengerti, tetapi juga mau dan bisa melakukan suatu anjuran yang ada hubungannya dengan kesehatan. (Ali, Zaidin. 2010: 5)

Berdasarkan latar belakang masalah tersebut diatas peneliti tertarik untuk meneliti "Perbedaan motivasi wanita PUS usia 35-49 tahun untuk menggunakan Implant sebelum dan setelah diberi penyuluhan di Dusun Mojolegi Desa Bendo Kecamatan Pare"

\section{Metode Penelitian}

Desain dalam penelitian ini menggunakan pre-experiment design dengan model one group pre-test post-test design yaitu eksperimen hanya melibatkan satu kelompok subjek yang diobservasi sebelum dilakukan intervensi, kemudian diobservasi lagi setelah intervensi (Nursalam: 2008). Populasi dalam penelitian ini adalah seluruh Wanita PUS Usia 35-49 tahun di Dusun Mojolegi Desa Bendo Kecamatan Pare yang sudah memiliki anak, belum ber-KB atau masih menggunakan kontrasepsi non-MKJP. Besarnya populasi dalam penelitian ini adalah 72 orang. Besar sampel 61 responden dengan tehnik sampling simple random sampling. Varibel penelitian adalah motivasi menggunakan implant sebelum penyuluhan dan motivasi setelah penyuluhan. Analisa data menggunakan Wilcoxon Match Pairs Test.

\section{Hasil Penelitian \\ Data Umum}

Berdasarkan hasil penelitian didapatkan sebagian besar responden berusia 35-40 tahun (40,98\%), sebagian besar responden berpendidikan terakhir SD (44,26\%), lebih dari setengah responden adalah sebagai ibu rumah tangga $(54,10 \%)$, lebih dari setengah responden saat ini menggunakan KB suntik 3 bulan $(54,10 \%)$, hampir setengah dari 61 responden memiliki 2 anak $(47,54 \%)$, hampir seluruh responden sudah tidak ingin memiliki anak lagi $(90,16 \%)$, hampir seluruh responden $(83,61 \%)$ belum pernah mendapatkan penyuluhan tentang KB Implant

\section{Data Khusus}

1. Frekuensi Motivasi wanita PUS Usia 35-49 tahun untuk Menggunakan Implant Sebelum Diberi Penyuluhan.

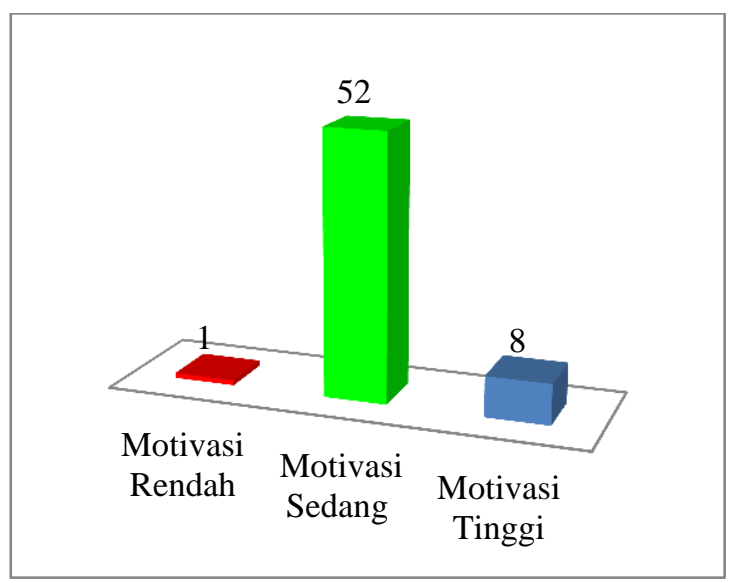

Gambar 1 Distribusi Frekuensi Motivasi wanita PUS usia 35-49 tahun untuk Menggunakan Implant Sebelum Diberi Penyuluhan di Dusun Mojolegi Desa Bendo Kec. Pare

Berdasarkan gambar 1 dapat dijelaskan hampir seluruhnya sudah memiliki motivasi tingkat sedang $(85,25 \%)$ untuk menggunakan Implant sebelum mendapat penyuluhan.

2. Frekuensi Motivasi wanita PUS usia 35-49 tahun untuk Menggunakan Implant Setelah Diberi Penyuluhan

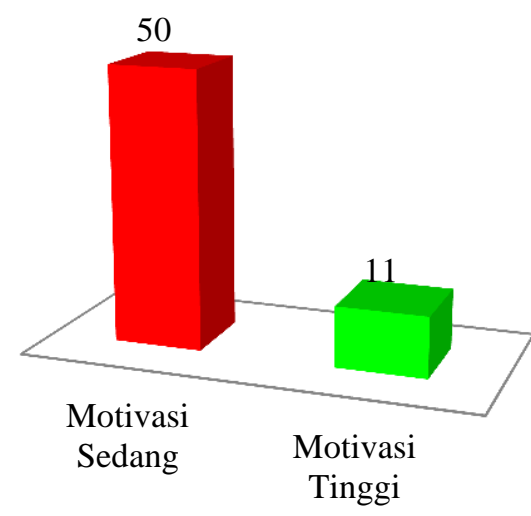

Gambar 2 Distribusi Frekuensi Motivasi wanita PUS usia 35-49 tahun untuk Menggunakan Implant Setelah Diberi Penyuluhan di Dusun Mojolegi Desa Bendo Kec. Pare 
Berdasarkan gambar 2 dapat dijelaskan hampir seluruhnya memiliki motivasi kategori sedang (82\%) untuk menggunakan Implant setelah mendapatkan penyuluhan.

3. Frekuensi Motivasi Wanita PUS Usia 35-49 tahun untuk Menggunakan Implant Sebelum dan Setelah Diberi Penyuluhan.

Perbedaan motivasi wanita PUS usia 35-49 tahun untuk menggunaakan Implant sebelum dan setelah diberi penyuluhan di Dusun Mojolegi Desa Bendo Kec. Pare ditampilkan dalam bentuk tabel di bawah ini:

Tabel 1 Distribusi Frekuensi Motivasi Wanita PUS Usia 35-49 Tahun untuk Menggunakan Implant Sebelum dan Setelah Diberi Penyuluhan.

\begin{tabular}{cccccc} 
Kriteria & \multicolumn{4}{c}{ Sebelum dan sesudah } & \multirow{2}{*}{ T } \\
\cline { 2 - 5 } & $\begin{array}{c}\mathbf{X 1} \\
\text { (f) }\end{array}$ & $\%$ & $\mathbf{X 2 ( f )}$ & $\%$ & \\
\hline $\begin{array}{c}\text { Motivasi } \\
\text { Rendah }\end{array}$ & 1 & 1,64 & 0 & 0,00 & $\mathrm{~T}=213$ \\
$\begin{array}{c}\text { Motivasi } \\
\text { Sedang }\end{array}$ & 52 & 85,25 & 50 & 81,97 & $\mathrm{Z}=-5,2$ \\
$\begin{array}{c}\text { Motivasi } \\
\text { Tinggi }\end{array}$ & 8 & 13,11 & 11 & 18,03 & \\
\hline
\end{tabular}

Hasil penelitian tersebut dianalisis dan dihitung menggunakan teknik analisis data wilcoxon match pairs test. Kemudian hasil jenjang terkecil dimasukkan dalam rumus $\mathrm{z}$ dan hasilnya dibandingkan dengan $\mathrm{z}$ tabel. Ternyata hasil $\mathrm{z}$ hitung lebih besar dari harga $\mathrm{z}$ tabel, maka dapat disimpulkan bahwa ada perbedaan motivasi wanita PUS usia 35-49 tahun untuk menggunakan implant sebelum dan setelah diberi penyuluhan.

\section{Pembahasan}

1 Motivasi wanita PUS usia 35-49 tahun untuk menggunakan implant sebelum diberikan penyuluhan

Menurut F. Herzberg dalam Suwatno (2011: 175), faktor yang mempengaruhi motivasi antara lain minat, sikap positif, kebutuhan motivator dan faktor kesehatan. Hasil penelitian deskriptif dengan pendekatan cross sectional yang dilakukan oleh Fitriani (2013) tentang gambaran minat wanita usia subur dengan pemilihan alat kontrasepsi implant di wilayah kerja Puskesmas Meureudeu menunjukkan bahwa Umur, pengetahuan dan pendidikan mempengaruhi minat wanita subur untuk menggunakan Implant. WUS usia >35 tahun menunjukkan minat yang lebih tinggi dibandingkan usia dibawahnya untuk menggunakan Implant Semakin tinggi pendidikan dan pengetahuan WUS semakin tinggi pula minat menggunakan Implant. Ini sejalan dengan penelitian analitik dengan pendekatan cross sectional yang dilakukan oleh Susanti (2013) tentang faktor-faktor yang berhubungan dengan minat ibu terhadap penggunaan Implant di Puskesmas Ome. Susanti menambahkan, tingkat ekonomi juga mempengaruhi minat ibu untuk menggunakan Implant.

Menurut asumsi peneliti, umur, pengetahuan, pendidikan, dan ekonomi sangat berpengaruh terhadap motivasi wanita PUS untuk menggunakan implant. Usia responden yang >35 tahun dalam penelitian ini mendorong motivasi responden untuk menggunakan Implant karena dari segi kebutuhan mereka membutuhkan Implant sebagai kontrasepsi jangka panjang untuk mencegah terjadinya kehamilan, dibuktikan dengan $84 \%$ responden menyatakan sudah tidak ingin memiliki anak lagi. Namun pendidikan, pengetahuan, dan tingkat ekonomi yang rendah menekan motivasi responden untuk menggunakan implant. Hanya 16\% responden yang menyatakan sudah pernah mendapatkan informasi tentang Implant sementara $84 \%$ lainnya belum pernah, ini menunjukkan bahwa pengetahuan responden tentang implant sangat minim. Selain itu dari segi ekonomi yang rendah, anggapan bahwa biaya pemasangan dan pelepasan implant yang mahal akan 
menyurutkan motivasi responden untuk menggunakan Implant. Beredarnya rumor yang tidak benar mengenai kontrasepsi Implant seperti kapsul Implant dapat hilang dalam tubuh, dapat berjalan ke organ lain dalam tubuh dan teknik pembedahan saat pemasangan yang mengerikan dan menyakitkan membuat masyarakat takut untuk menggunakan Implant.

2 Motivasi wanita PUS usia 35-49 tahun untuk menggunakan Implant setelah dilakukan penyuluhan

Menurut Azrul Anwar dalam Zaidin Ali (2010) penyuluhan adalah kegiatan pendidikan yang dilakukan dengan cara menyebarkan pesan, menambahkan keyakinan, sehingga masyarakat tidak saja sadar, tahu dan mengerti, tetapi juga mau dan bisa melakukan suatu anjuran. Menurut Israr Y., dkk (2008), rendahnya MKJP termasuk Implant di Indonesia karena pengetahuan klien dan kurangnya kualitas sosialisasi/ KIE MKJP. Mereka lebih banyak mendapat informasi dari teman atau keluarga tentang non-MKJP seperti suntik dan pil. Ini menunjukkan perlu lebih ditingkatkan pengenalan KBMKJP. (BKKBN, 2009). Penelitian yang dilakukan oleh Fitriani, Susanti, dan Jasmaniar menunjukkan bahwa pengetahuan sangat berpengaruh terhadap minat ibu untuk menggunakan Implant.

Menurut asumsi peneliti penyuluhan yang dilakukan selama penelitian memberi tambahan informasi tentang KB implant juga meluruskan rumor-rumor yang tidak benar tentang implant misalnya seperti rumor bahwa implant dapat berjalan/ berpindah tempat dari lengan ke organ tubuh lain atau implant dapat hilang dalam tubuh, dan teknik pembedahan Implant yang mengerikan dan menyakitkan. Penyuluhan dilakukan dalam 2 waktu, dihadiri oleh 31 peserta pada kelompok pertama dan 30 peserta pada kelompok kedua, masing-masing 120 menit, menggunakan metode ceramah dengan memberikan informasi mengenai
KB implant secara lengkap mulai dari pengertian, efektivitas, cara kerja, keuntungan, efek samping, indikasi, kontraindikasi, waktu pemasangan, dengan menyertakan gambar kapsul implant sebagai alat peraga sehingga responden dapat melihat nyata inti materi sehingga lebih mudah mencerna dan menangkap makna materi yang disampaikan, penyuluhan juga menghadirkan akseptor implant yang telah 5 tahun menggunakan Implant untuk menceritakan pengalaman menguntungkan selama menggunakan Implant sehingga dapat menambah keyakinan responden.

Peneliti dengan dibantu oleh bidan juga memberikan informasi mengenai safari KB yang akan dilaksanakan pada tanggal 16 - 19 Juni 2014 sehingga tingkat ekonomi yang rendah tidak lagi menjadi penghambat motivasi responden untuk menggunakan Implant. Anggapan bahwa biaya pemasangan implant yang mahal dapat disingkirkan karena adanya safari KB yang memungkinkan responden mendapatkan pelayanan implant secara gratis sehingga motivasi responden untuk menggunankan implant meningkat.

Pada akhir sesi penyuluhan peneliti mengadakan tanya jawab dengan dibantu oleh bidan dan akseptor KB Implant yang dihadirkan. Banyak responden yang mengajukan pertanyaan, hal ini menunjukkan bahwa penyuluhan telah menimbulkan ketertarikan pada Implant yang selama ini mereka abaikan karena tidak begitu mengenal kontrasepsi ini. Dengan tanya jawab, responden dapat mengutarakan ketidaktahuannya tentang KB Implant sehingga dengan mendapatkan jawaban yang tepat dari petugas dapat menghindari adanya kesalahpahaman tentang KB Implant yang dapat berujung pada rumor yang membuat Implant dihindari oleh masyarakat. 
3 Perbedaan motivasi wanita PUS usia 35-49 tahun untuk menggunakan implant sebelum dan setelah diberi penyuluhan

Menurut asalnya motivasi dikelompokkan menjadi dua, motivasi internal dan eksternal. Masing-masing dibagi lagi menjadi dua, positif dan negatif. Salah satu contoh motivasi yang berasal dari luar (motivasi eksternal) yang bersifat positif adalah promosi/ penyuluhan (Irianto, Anton. 2005).

Menurut penelitian eksperimen semu dengan menggunakan model one group pretest - posttest yang berjudul perbedaan pengetahuan sebelum dan sesudah penyuluhan tentang kontrasepsi Implant oleh Ely Rohmawati (2011), didapatkan adanya perbedaan pengetahuan tentang kontrasepsi implan pada wanita usia subur sebelum dan setelah penyuluhan dengan $\rho$ value $=0,00$, yaitu pengetahuan wanita usia subur meningkat setelah mendapat penyuluhan. Penelitian yang dilakukan oleh Fitriani, Susanti, dan Jasmaniar menunjukkan bahwa pengetahuan sangat berpengaruh terhadap minat ibu untuk menggunakan Implant.

Menurut asumsi Peneliti, adanya peningkatan pengetahuan responden oleh karena mendapatkan penyuluhan tentang kontrasepsi Implant menyebabkan meningkatnya motivasi responden untuk menggunakan Implant. Hal ini sejalan dengan penelitian yang dilakukan oleh Fitriani, Susanti, dan Jasmiar di atas yang menyebutkan bahwa pengetahuan sangat berpengaruh terhadap minat responden untuk menggunakan Implant. Minat merupakan salah satu faktor yang dapat menimbulkan motivasi. Dengan adanya peningkatan minat, maka akan memacu peningkatan motivasi pula sehingga penyuluhan tentang kontrasepsi implant ini memberikan pengaruh terhadap motivasi responden untuk menggunakan implant. Dengan demikian dapat disimpulkan ada perbedaan motivasi wanita PUS usia 35-49 tahun untuk menggunakan implant sebelum dan setelah mendapat penyuluhan.

\section{Kesimpulan}

1. Motivasi wanita PUS usia 35-49 tahun untuk menggunakan Implant sebelum diberi penyuluhan menunjukkan kategori sedang

2. Motivasi wanita PUS usia $35-49$ tahun untuk menggunakan Implant setelah diberi penyuluhan menunjukkan kategori sedang.

3. Ada perbedaan motivasi wanita PUS usia 35-49 tahun untuk menggunakan Implant di Dusun Mojolegi Desa Bendo Kec. Pare.

\section{Saran}

Setelah melakukan penelitian tentang perbedaan motivasi wanita PUS usia 3549 tahun untuk menggunakan Implant sebelum dan setelah diberi penyuluhan di Dusun Mojolegi Desa Bendo Kecamatan Pare Kabupaten Kediri, peneliti menyarankan kepada:

1. Peneliti Selanjutnya

Dari kesimpulan yang didapat bahwa ada perbedaan motivasi wanita PUS usia 35 - 49 tahun untuk menggunakan Implant sebelum dan setelah diberi penyuluhan, disini berarti penyuluhan berpengengaruh terhadap motivasi ibu untuk menggunakan Implant sehingga diharapkan pada penelitian selanjutnya dibahas mengenai faktor-faktor yang berpengaruh terhadap pemilihan kontrasepsi Implant.

\section{Tempat penelitian}

Bidan diharapkan dapat lebih meningkatkan pemberian informasi tentang kontrasepsi implant secara lebih lengkap meliputi cara kerja implant, keuntungan dan kerugian implant, indikasi dan kontraindikasi, biaya pemasangan implant, dan mengenai safari KB. Bidan juga dapat menggunakan alat bantu berupa flipchart sehingga informasi yang diterima jelas karena pada flipchart 
terdapat gambar dan penjelasan yang mudah dimengerti.

\section{Daftar Pustaka}

Maulana, Heri D. J. 2012. Promosi Kesehatan. Jakarta: EGC

Arum, Dyah Noviawati S., dkk. 2009. Panduan Lengkap Pelayanan KB Terkini. Mitra Cendikia: Yogjakarta.

Hartanto, Hanafi. 2004. Keluarga Berencana dan Kontrasepsi. Pustaka Sinar Harapan: Jakarta.

Notoatmodjo, Soekidjo. 2007. Promosi Kesehatan \& Ilmu Periaku. Jakarta: Rineka Cipta.

Everett, Suzanne. 2012. Buku Saku Kontrasepsi dan Kesehatan Seksual Reproduktif. Jakarta: EGC.

Saifuddin, Abdul Bari. 2010. Buku Panduan Praktis Pelayanan Kontrasepsi, Edisi Ke-2. Jakarta: YBP-SP.

Manuaba, Ida Bagus Gde, dkk. 2010.Ilmu Kebidanan, Penyakit Kandungan dan KB untuk Pendidikan Bidan. Edisi 2. Jakarta: EGC.

Nursalam. 2009. Konsep dan Penerapan Metodologi Penelitian Keperawatan. Jakarta: Salemba Medika.

Saryono, dkk. 2013. Metodologi Penelitian Kualitatif dan Kuantitatif dalam Bidang Kesehatan. Yogyakarta: Nuha Medika.

Notoadmodjo, $\quad$ Soekidjo. 2010. Metodologi Penelitian Kesehatan. Jakarta: Rineka Cipta.
Sugiyono. 2010. Statistika untuk Penelitian. Bandung: Alfabeta.

Ali, Zaidin. 2010. Dasar-dasar Pendidikan Kesehatan Masyarakat dan Promosi Kesehatan. Jakarta: Trans Info Media.

Syafrudin, Yudhia Fratidhina. 2009. Promosi Kesehatan untuk Mahasiswa Kebidanan. Jakarta: Trans Info Media.

Hidayat, A. Aziz Alimul. 2009. Metode Penelitian Kebidanan \& Teknik Analisis Data. Jakarta: Salemba Medika.

Suwatno dan Donni J. P. 2011. Manajemen SDM dalam Orgnaisasi Publik dan Bisnis. Bandung: Alfabeta.

Mayliana, Esther, Herminarto Sofyan. 2013. Penerapan Accelerated Learning dengan Pendekatan SAVI untuk Meningkatkan Motivasi dan Hasil Belajar Kompetensi Menggambar Busana. Jurnal Pendidikan Vokasi. Vol 3, Nomor 1, Februari 2013. Halaman 14-28

Susilawati, Fitriani. 2013. Gambaran Minat Wanita Usia Subur dengan Pemilihan Alat Kontrasepsi Implant di Wilayah Kerja Puskesmas Meureudu Kecamatan Meureudu Kabupaten Pidie Jaya. Jurnal Karya Tulis Ilmiah. Halaman 1-10.

Musdalifah, Mukhsen Sarake, dkk. 2013. Faktor yang Berhubungan dengan Pemilihan Kontrasepsi Hormonal Pasutri di Wilayah Kerja Puskesmas Lampa Kecamatan Duampanua Kabupaten Pinrang 2013. Halaman 1-13. 
Jasamaniar. 2013. Faktor-faktor yang Mempengaruhi Minat Akseptor KB Terhadap Pemakaian Alat Kontrasepsi Implant di Puskesmas Simuelue Timur. Halaman 1-8.

Susanti, Mona Wowor, dkk. 2013. FaktorFaktor yang Berhubungan Dengan Minat Ibu terhadap Penggunaan Alat Kontrasepsi Implant di Puskesmas Ome Kota Tidore Kepulauan. ejournal keperawatan (e-Kp) Volume 1. Nomor 1. Agustus 2013. Halaman 1-5.

Rohmawati, Ely, Dkk. Perbedaan Pengetahuan Sebelum Dan Sesudah Penyuluhan Tentang Kontrasepsi Implan Di Rw IV Desa Wonolopo Kecamatan Mijen Kota Semarang. Hamalan 1-9.

BKKBN. 2009. Analisa Lanjut SDKI 2007, Faktor yang Mempengaruhi Pemakaian Kontrasepsi Jangka Panjang (MKJP). Jakarta: BKKBN.

Haska, Ardani. 2003. Hubungan Motivasi Mahasiswa Terhadap Sadari di Program Studi Kebidanan Kediri. Karya Tulis yang Tidak dipublikasikan.

BPS, BKKBN, dan Kemenkes. 2012. Laporan Pendahuluan Survei Demografi dan Kesehatan Indonesia (SDKI). 